\title{
MAI I TE WHENUA KI TE RANGI \\ TRANSFERRING MĀORI PEDAGOGICAL PRACTICES INTO CYBERSPACE
}

\author{
Sheryl Lee Ferguson
}

\begin{abstract}
E-Learning has become the norm in many tertiary institutes in Aotearoa New Zealand. The digital age is upon us and as change agents in a Māori tertiary environment, Māori educators are constantly having to keep abreast of new and innovative ways of teaching and learning. Te Iti Rearea, Bachelor of Teaching and Learning (o-8) Early Years Māori Medium degree at Te Whare Wānanga o Awanuiārangi, has recently made the move from the conventional face-to-face model of teaching and learning to the mixed mode model. ELearning is one of the modes of delivery for this programme. The degree is a Māori medium degree and ako, or the Māori preferred reciprocal pedagogy, underpins the programme. The transfer of Màori pedagogical practices from the conventional face-to-face model to the e-Learning environment can seem like a mammoth task, but is it? This paper outlines some of the key indicators for the successful transfer of Maori pedagogical or adragogical practices from the conventional to the e-Learning environment, drawing upon recent case studies completed by the author.
\end{abstract}

\section{INTRODUCTION}

Many programmes within educational institutes both nationally and internationally, have adopted e-Education (e-Learning and e-Teaching) as a method for course content delivery. Te Whare Wānanga o Awanuiārangi, the indigenous university ${ }^{1}$ in Whakatāne, New Zealand, is no different, with some of the Māori programmes implementing e-Education as a way forward for students and/or educators geographically disadvantaged or those residing outside of the tribal boundaries. The Ministry of Education's e-Learning Advisory Group (2002:7) in New Zealand define e-Education as 'teaching and learning in an Internet environment'. Education via the eWānanga system has been part of the teaching and learning landscape at Te Whare Wānanga o Awanuiārangi 
since the introduction of Te Tohu Paetahi Mātauranga Māori Bachelor of Māori Education eWānanga in 2002 (Laws, 2006). Te Whare Wānanga o Awanuiārangi's implementation of e-Learning was aptly timed to coincide with the launch of the Tertiary Education Strategy 2002-2007 and the objectives outlined therein. These were to 'strengthen system capability and quality' and to 'develop the skills New Zealanders need for our knowledge society' (Tertiary Education Strategy. 2002). The knowledge society today involves the use of technology within the teaching and learning environment, as well as in the homes of many New Zealanders. The knowledge society mentioned above includes the Māori knowledge society. The Māori knowledge society is inclusive of āhuatanga Māori. Āhuatanga Māori is whakapapa (genealogy), karakia (prayer), whaikōrero (oratory), tikanga (customs), te reo (language), kawa (protocols), whakataukii (proverbial statements), mōteatea/waiata (chants/ songs) and Māori epistemology (Mead, 2003; Nepe, 1991; Pere, 1982).

\section{KARAKIA/MIHIMIHI/TE REO}

Te reo Māori me ōna tikanga (Māori language and customs) is at the forefront of many of the programmes currently being taught at the Wānanga. The inclusion of an e-Learning component into some of the programmes has meant a total mind shift in the way we think about teaching and learning. This new mode of delivery and teaching is currently an integral part of Te Iti Rearea Bachelor of Teaching and Learning (o-8) Early Years Māori Mediums' mixed mode delivery model. Historically, Māori have had concerns about e-Learning and what effect it may have on the Māori preferred pedagogy or ako. Te reo Māori me ona tikanga me te kawa ${ }^{2}$ remains an important element in the mixed mode delivery for Te Iti Rearea programme. Many of the students from the 2006 case study insist on writing a 'karakia' (prayer) or a 'mihimihi' (greeting) before they even start to complete their tasks for their course. Cultural protocols cannot be excluded from the e-Learning environment although there is currently no Māori framework for e-Learning and e-Teaching.

A constant challenge for Māori e-Pouako, or Māori online lecturers, is to try to retain Mãori pedagogical practices in the e-Learning and e-Teaching environment. Āhuatanga Māori can be settling or comforting for many Māori students who have te reo Māori as their first language and have been raised in traditional Māori customs and protocols. The Iti Rearea e-Learning environment is conducive to the cultural needs of the students. Students are encouraged to complete all their work in te reo; reflecting the fact that most of the students from one of the case studies mentioned above are native speakers of te reo Māori. It is important to remember that while some individuals will 
always prefer the traditional face-to-face methods of teaching and learning, there will also be others who prefer online interaction (Ministry of Education, 2002; Stephenson, 2001).

The Māori language, or te reo Māori, remains one of the most important factors when considering the transfer of a cultural pedagogy from conventional learning environments to cyberspace, especially for the Iti Rearea Bachelor of Teaching and Learning Early Years Māori Medium. A well known Māori scholar from the Tuhoe region in the Eastern Bay of Plenty, John Te Rangianiwaniwa Rangihau, reiterated the importance of te reo Māori with the following statement, 'Ko te reo te poutāwha e iri ai ngā tāonga katoa ā kui mā $\bar{a}$ koro mä' or 'The language is the storehouse that holds all the treasures of our ancestors'. The treasures this storehouse holds are the very essence of the culture, therefore te reo Māori must be the driving force behind the Māori preferred pedagogy or ako. Nepe suggests that te reo Māori is a 'vital strand' for the transmission of Māori knowledge and that 'no other language will be able to convey the intricacies of this knowledge' (1991:55). Joshua Fishman, the internationally renowned sociolinguist, believes that 'culturally specific language is often the vehicle and the beneficiary of such mystic beliefs' (2001:5). The e-Learning environment at Te Whare Wānanga ō Awanuiārangi has an optional te reo Māori theme that students and lecturers can easily shift to from the English version. While technical issues around translation may arise, transferring the Māori language into the e-Learning environment is not an insurmountable task. Macron use with the previous Learning Management system posed a problem as the system did not accept the macrons when transferred. However, this issue was resolved in 2009 when Te Whare Wānanga o Awanuiārangi started utilising Moodle, a new learning management system.

The Whare Wānanga o Awanuiārangi adopted a unique, hybrid terminology in 2002. The preferred terminology for Te Iti Rearea includes hybridised words such as, e-Pouako (online educator), e-Mahara (an online journal for students on practicum), e-Kanohi (video messaging), e-Kete (an online private student folio to which only students and pouako have access), e-Pātai (questions and answers folder), e-Kōrero (asynchronous discussion or messaging boards), eWhakangungu (associate teachers folder), and e-Whatu (synchronous online video conferencing) (Laws, Ferguson \& Werahiko, 2008). The hybridisation of the Māori and English language has been widely used in tertiary institutions in Aotearoa since the dawning of the technological age. For some Māori academics, however, it is easy to establish a debate about the hybridisation of te reo and the bastardisation of the Màori language. 
Karakia and mihimihi as introductory protocols are not practiced by Māori alone; indeed some form of introductory protocols are givens within all cultures. There is a fine line between a protocol and a custom. According to one popular source, a protocol is etiquette whilst a custom is a habitual practice or a usual way of acting in certain circumstances (Dictionary.com, 2008). Therefore, karakia and mihimihi can be part of the customs of a culture and or a protocol. In this instance, I refer to karakia and mihimihi as protocols as they are both considered part of ceremonial practices and social behaviour in te ao Māori ${ }^{3}$ (Mead, 2003). One could argue that group dynamics are the same regardless of the teaching and learning environment, so transferring from one learning environment into another merely requires a mind shift by the users. Thus, the biggest barrier to the successful transfer of courses from the conventional classroom to the e-Learning environment remains in the hands of the users: the teachers or lecturers and the students.

Whakapapa contains the history of the family, sub-tribal groups and tribes, and is important for Māori as whakapapa is what links Māori to the whenua or land. According to Mead (2003:218) the 'whakapapa principle' is one of 'the most important and fundamental criterion of membership in sub tribal groups'. Knowing the 'whakapapa' of your students in a Māori teaching and learning context is important as it enables the teacher to identify and acknowledge the diversity of the students. For example, personal observations have revealed that certain skills and attributes are handed down from generation to generation. Teachers who know and understand the whakapapa of their students are less likely to discriminate against the student if they display some of these attributes - whether good or not so good - in the classroom. Therefore the whakapapa principle is not only essential for Māori but makes up a big part of the Māori knowledge society.

Karakia or prayer remains an integral part of the Māori knowledge society today. Traditionally, karakia were performed before any event took place: the cutting down of trees, the opening of buildings or whare tipuna (meeting houses), the birth of children, during and after the death of iwi members and many other events. Karakia is a ritual that has survived the waves of colonisation in Aotearoa New Zealand and Māori still perform karakia in the above mentioned situations. Many of the traditional karakia (see Smith, 1978) contain cosmological history and whakapapa of Māori. Therefore, karakia remains important in all Mãori teaching and learning contexts, including the e-Learning and e-Teaching context. 
Andragogy is the term used to explain the adult teaching and learning context, processes and strategies, whereas pedagogy is a term used to refer to teaching and learning with children. However, for this section of the article, pedagogy is the preferred term as the Bachelor of Teaching and Learning is a teacher education programme and student teachers are trained to teach young children. Although there are noticeable differences between andragogy and pedagogy, Māori epistemology underpins both within the Māori teaching and learning context. Therefore, for this article, the term 'ako' represents both the adult and child teaching and learning processes. Ako is a reciprocal teaching and learning process, where shared teaching and learning transpire. Previous research suggests that face-to-face traditional teaching and learning is the preferred method for Māori teachers and students (Pere 1992; Pihama et al. 2004). These studies and others suggest that the online learning environment is not always congruent with Māori pedagogies. For example, Anderson (2005:176) suggests that Māori education is 'customarily undertaken in face-to-face (kanohi-ākanohi) situations, recognizing the need for an intimate connection between teacher and learner'. Although Māori participation in the Iti Rearea e-Learning environment is developing and Māori students are coping well with the new medium, Māori are still not high achievers in the technological field (Ministry of Education, 2002). According to one study conducted about e-Learning and e-Teaching, relationships between students and teachers in this environment is different to those formed in conventional face-to-face teaching and learning environments (Maeroff, 2003). However, personal experiences teaching Māori adult learners in the e-Learning environment have revealed that many of the relationships formed are similar to those formed in the conventional (face-toface classrooms) and are sometimes more intense. For example, the greater physical distance of the student from the lecturer can increase the desire to communicate via computer-assisted means.

Ako encompasses many aspects of āhuatanga Māori or Māori ways, including wairuatanga or spirituality. A constant challenge for the Iti Rearea teaching team is to retain these concepts in the e-Learning environment. The values and beliefs inherent in western philosophy accept that learning and development occurs within the hinengaro or mind. However, Māori believe that learning and development occurs through 'wairua' and that 'hinengaro' is only one part of that wairua (Nepe, 1991). The 'wairua' or the spirit of students is very important and should be cared for in both the conventional and e-Learning environment. For example, the language of instruction that the teacher uses in the online classroom needs to be encouraging and positive. Although the teacher 
cannot see their students, it is still possible to 'hurt their feelings' through virtual communication. My own experience as a frequent user of the Learning Management System to conduct student pastoral care, and as an online student, testifies to this statement. However, it must be noted that positive reinforcement alone does not always settle the 'wairua' of the student. Methods of settling or comforting the wairua or 'whakatau wairua' come in many shapes and forms. For example, karakia or prayer is one form of whakatau wairua, as is waiata whakangahau (social singing) and himene (hymns). Physical activity before a class has also known to be useful in settling the student before class instruction begins. This is not a new concept, and many teachers will include a fitness session, brain gym session and/or waiata (singing) before formal instruction in the classroom.

The tuakana/teina strategy or the grouping of older children with younger children is included in the ako pedagogy. Literally, tuakana means older sibling of the same sex, and teina means younger sibling of the same sex. In the educational context, the tuakana/teina strategy involves grouping older students with younger students. This strategy works well in multi-level classrooms in Māori immersion schools, but it has also proved effective with adult learners in the Iti Rearea teaching and learning environment, although it has not been trialled in the e-Learning and e-Teaching context. However, based on personal observations of new students entering the e-Learning context, having an experienced user of the eWānanga site (usually students from the previous intake) is very helpful to the new e-Learner. The tuakana is there to guide the teina with navigation and the usual operations in the e-Learning environment. This strategy is particularly useful if the pouako or lecturer is not available or if there are other students needing their attention.

The transfer of this cultural pedagogy with all its holistic components is easily achieved with what is called 'whakapono' or 'belief in the process'. If the lecturer believes and practices Mãori pedagogy, then the transferral of ako need not be difficult. The lecturer or the facilitator plays an important part in the success of students in the e-Learning environment. Research studies reiterate the importance of the teacher as being the leader in the e-Learning and e-Teaching environment and taking responsibility for easing the transition from conventional learning to e-Learning (Campbell, 2003; Stephenson, 2001). Weller (2002) insists that a pedagogical approach to e-Learning can be influenced by the lecturer, depending on the lecturer's own values and beliefs. If the lecturer has Māori values and beliefs then this is what influences the student. Consequently, this leads to the assumption that the successful transfer of cultural pedagogy from the conventional environment to the e-Learning 
environment is largely the responsibility of the lecturer or facilitator. My own experiences as an online lecturer both for an urban mainstream university and a whare wānanga can attest to this as students will be as enthusiastic as their lecturer for certain subjects, regardless of the delivery mode. If students sense the enthusiasm and passion of the lecturer or facilitator, then they are more likely to want to learn what is being delivered, and to also want to do well in the subject area. If the lecturer rushes through the lesson and does not allow students to question or critique the subject, then they are less likely to want to excel in the subject area. In both the face-to-face learning environment and the e-Learning environment, students' ability to question and critique subject content is very important. However, these questions need to be relevant to the topic and time should not be wasted on unnecessary debates that can annoy both the teacher and the other students. The asynchronous discussion forum provides an environment for questioning, critiquing and debating issues and is conducive with the different student learning styles. The absence of visual cues in the e-Learning environment can empower some students who are usually not so vocal in the conventional classroom (Campbell, 2003).

Palloff and Pratt (2001: 68) suggest that only a few courses do not transfer into the e-Learning environment. These include lab sciences, applied art, counselling skills, and speech. On the other hand, there is minimal research on the transfer of a cultural or indigenous pedagogy into this environment and very limited guidelines developed nationally for effective e-Learning practices for Māori (Laws, Ferguson and Werahiko, 2008). One advantage of the e-Learning environment is that students who are usually quiet in a conventional classroom will often find their voice among the group in the online classroom. They have the time to critically reflect on previous discussions in the forum and have time to construct new knowledge from perusing other contributions made by their peers and the lecturer. Weller (2002:65) maintains that constructivism involves the learner constructing their own knowledge based on their experience[s] and relationship[s] with concepts. In the e-Learning environment, the learner has the opportunity to not only construct new knowledge pertaining to the course, but new knowledge that includes concepts and skills in facilitation, as well as awareness of technological innovations and advancements.

Values and beliefs are what bind a culture. Believing in a concept or a pedagogy has been the driving force behind the education reforms of the $1980 \mathrm{os}$ in Aotearoa New Zealand. For any culture, a shared belief in a collective vision and set of cultural objectives strengthens the bonds between its members, as well as the ability to achieve its objectives. Two studies conducted for the 
Ministry of Education's Tertiary e-Learning Guidelines (Ferguson, 2006; Ferguson 2008) highlight a different perspective on the ways that Māori pedagogy can be successfully transferred into the e-Learning environment. As argued above, successful transferral depends upon the presence of certain elements and practices, and importantly, on the cultural belief that Māori can be leaders in e-Learning.

\section{MĀORI AND E-LEARNING - THE COLLECTIVE VISION}

It is a well known fact in Māori educational circles that when grouped together or when working as a collective, Māori will thrive and succeed. This has been well documented by educationalists in previous publications (Durie, 1994; Hemara, 2000; Pere, 1982; Nepe, 1991; Pihama et al. 2004). Whānau (family), hapū (sub tribe) and iwi (tribe) groups tend to have better educational outcomes when involved with their children's education. This is a holistic approach to education. Holistic education is not a new concept for Māori, and is evident in the development of Kōhanga Reo (Māori language 'nests' or schools), Kura Kaupapa (Māori immersion schools) and Whare Wānanga (tribal or indigenous universities). Miller et al. (2005:2) suggest there are three basic principles of holistic education, 'connectedness, inclusion and balance.' These three principles are givens within Māori educational organisations and should simply be 'transferred' over into the e-Learning and e-Teaching environment. However, it is important to remember that not all learners, whether in the e-learning of conventional classroom environment, learn in the same way; students have individual learning styles. While taking this into account, the author insists that collectivism is a key element to the success of Māori learners in this environment. Collectivism in this sense is the grouping together of students from one culture and the collective vision that the learners share, rather than grouping students according to their individual learning styles. For example, the collective vision for the students involved in the 2006 case study was to use the technology to enhance their learning and to achieve passes in their year one papers. A further collective vision of the group, including the lecturer, was to enable students greater choice in their methods of learning. These learners all had individual learning styles, some preferring asynchronous communication, while others preferred synchronous communication such as Skype technology. ${ }^{4}$ It is important to provide students with various technological options when delivering via the mixed mode model as it should not be taken for granted that all Māori students prefer the face-to-face, online (Skype or video messaging) approach. There will be some students who are comfortable with the instant messager' or written messages in online forums. However, it is important to emphasise in these learning contexts that whatever the individual learning 
style or preference, the vision remains collective.

The 2006 case study involved a group of Māori women, many of whom had very low computer literacy levels. A comparison was made between this relatively small group of students and a class at an urban University. Out of the $50+$ students in the class at the urban University, only five were Māori. These Māori students were not very active in the e-Learning environment. However, the interaction in the e-Learning environment with the Mãori group from the Wānanga was very different. These students were very 'vocal' and inter active in this environment which adds weight to former claims that when grouped together, Māori will thrive and succeed. Hine (2000:19) suggests that learners who use online 'text based environments have often exploited the potential for representing themselves in ways quite different from their offline personae'. This was not the case with the 2006 group of students, as the majority of them knew each other intimately before the start of the course. This fact alleviated the potential for representing themselves differently online. Active learning through student participation and dialogue in the e-Learning environment results in the construction of knowledge (Lynch, 2004). There is a myth about e-Learning that needs to be erased, as it is one that many educators use to justify their reluctance to adopt this mode of learning or teaching. That is, that the group dynamics in the conventional classroom and the e-Learning environment are fundamentally different. According to Lynch (2004) the same group dynamics are evident in both environments, conventional and online. Today, the students from the 2006 study group are competent, confident and comfortable in the e-Learning environment (Ferguson, 2008).

Since the implementation of e-Learning in tertiary institutions in Aotearoa New Zealand, there has been some resistance to this new mode of teaching and learning. The resistance toward the shift from conventional teaching and learning to the e-Learning environment is not a new trend, as noted by previous authors (Ministry of Education, 2002; Stephenson, 2001; Toffler, 1991; Weller, 2002). Admittedly, resistance has not been an issue with the programme at Te Whare Wānanga o Awanuiārangi and all lecturers have undertaken professional development in order to keep abreast of the new mode of delivery.

CURRENT INNOVARIONS AT TE WHARE WANANGA O AWANUIARANGI

In 2009 and with accreditation for mixed mode delivery, Te Iti Rearea Bachelor of Teaching and Learning is well underway with e-Learning and e-Teaching. Mixed mode delivery for the programme has enabled many Māori students 
the opportunity to access quality education from their own tribal areas. The mixed mode delivery model in this instance includes e-Learning, face-to-face weekend classes and self-directed learning by the student. The new Moodle Learning Management system currently being trialled is also proving to be successful. The Wānanga incorporates a unique online philosophy and methodology with 'eWānanga'. The eWānanga system has enabled staff to engage in new and emerging Information Communication Technologies, that are underpinned by Maori theory and practice. All content and resources, initiatives and methodologies, training and development, are designed to provide both staff and students with an online experience unique to the Wānanga. The eWānanga Centre for Creative Teaching and Learning was established in 2008 by Associate Professor Dr. Mark Laws to manage the 'eWānanga LMs', cultivate the 'eWānanga ethos', provide support for all online educators and students, and to undertake new emerging research and development initiatives (Laws, 2009, personal communication).

\section{CONCLUSION}

The illiterate of the 21st century will not be those who can not read or write, but those who can not learn, unlearn and relearn (Toffler, 1991:17)

This quote adequately describes the context in which we as Māori lecturers and students in a Māori institute teach and learn. Transferring cultural pedagogy into the e-Learning environment requires a mind shift by the users in the first instance. Mind shifts do not happen overnight, but they do and can happen. Patience, perseverance, determination, a futuristic vision and, most importantly, a belief by the users, are key elements that teachers, lecturers or facilitators of the e-Learning environment need to successfully guide and encourage students with e-Learning. Cultural values and beliefs, te reo Māori me ona tikanga and kawa are most important to ensure a safe learning environment for Māori students that challenges and promotes critical thinking skills and the construction of new knowledge for the new knowledge society. As Māori, we cannot afford to let go of our values and beliefs, language and customs merely because we are teaching and learning via a different mode. Every effort must be made to retain our language and culture regardless of the technological advances and innovations that we utilise in our classrooms. We have the capability to successfully transfer our own pedagogy into cyberspace through the 'learning, unlearning and relearning' process. Many students on the programme are in the process of learning, unlearning and relearning new information, particularly new technological information. Lecturers are also 
engaged in this process and are, for the first time in their teaching careers, having to rethink and reshape their own conventional ways of teaching and learning. Māori have the capability to be leaders in e-Learning in Aotearoa New Zealand. Further research and exploration of new technological developments would enhance the capacity of Māori to deliver quality e-Education to students throughout Aotearoa New Zealand.

NOTES

1 Graham Hingangaroa Smith, CEO of Te Whare Wānanga ō Awanuiārangi describes the Wānanga as an 'indigenous University'.

2 Te reo Māori me ōna tikanga - Māori language and customs, Kawa - Protocols.

3 Te Ao Māori - The Māori world.

4 Skype is a free video and audio resource that is easily downloaded from the Internet. Calls are free anywhere in the world, if one has an Internet connect and a webcam.

\section{REFERENCES}

Campbell, N. 2003 'So you want to teach online? It won't happen overnight but it can happen', Computers in New Zealand Schools, 15 (1):11-13, 25.

Dictionary.com. 2008 The Online Dictionary, http://dictionary.reference.com/, accessed 25/07/08.

Ferguson, S. 2006 'He whakamātau rangahau mo te ako-ā-ipurangi tuatahi mo Te Iti Rearea. Ministry of Education Tertiary eLearning Reference Group

E-Learning Guidelines for New Zealand'. http://elg.massey.ac.nz/index.php? title=Case_Study_People

Ferguson, S. 2008 'e-Aorangi Mātauranga Māori Motuhake. He whakamātau rangahau mō te ako-ā-ipurangi. Ministry of Education Tertiary e-Learning Guidelines for New Zealand'. http://elg.massey.ac.nz/index.php?title=E-Ao rangi_M\%C\$\%81tauranga_M\%C4\%81ori_Motuhake

Fishman, J.A. 2001 Can Threatened Languages be Saved?, Clevedon, UK: Multilingual Matters. 
Hemara, W. 2000 Mãori Pedagogies: A View from the Literature. Wellington: New Zealand Council for Educational Research.

Hine, C. 2000 Virtual Ethnography, London: Sage.

Laws, M., S. Ferguson, and H. Werahiko 2008 'Ngā Kaupapa Māori Arataki mō te eWānanga. Māori guidelines for eWānanga: The student online learning and management system. Ministry of Education Tertiary eLearning Guidelines for New Zealand'.

Lynch, M.M. 2004 Learning Online-A guide to success in the virtual classroom. London: Routledge Falmer.

Mead, H.M. 2003 Tikanga Maori: Living by Maori values. Wellington: Huia.

Maeroff, G.I. 2003 A Classroom of One: How Online Learning is Changing Our Schools and Colleges. New York: Palgrave Macmillan.

Miller, J., S. Karsten, D. Denton, D. Orr and C. Kates 2005 Holistic Learning and Spirituality in Education, New York: Suny Press, http://www.sunypress.edu/ details.asp?id=6106, accessed 29/04/08.

Ministry of Education 2002 Highways and Pathways Exploring New Zealand's E-Learning Opportunities. The Report of the E-Learning Advisory Group Wellington.

Ministry of Education. 2002 Tertiary Education Strategy 2002-2007. Wellington: Ministry of Education. http://www.minedu.govt.nz/web/downloadable/ dl7130_v1/tes.pdf, accessed 26/o6/o8.

Nepe, T. 1991 E hao nei e tēnei reanga Te Toi Huarewa Tipuna Kaupapa Māori - An Educational Intervention System, unpublished MA thesis. Auckland: University of Auckland.

Palloff, R. and K. Pratt 2001 Lessons from the cyberspace classroom: The realities of online teaching. San Francisco: Jossey-Bass.

Pere, R. 1982 AKO Concepts and Learning in the Maori Tradition, Te Kohanga Reo National Trust Board, Wellington New Zealand. 
Pihama, L., K. Smith, M. Taki and J. Lee 2004 A Literature Review on Kaupapa Maori and Maori Education Pedagogy, The International Research Institute for Maori and Indigenous Education.

Smith, P. 1978 Te kauae runga: the lore of the whare wananga, New York: AMS Press.

Stephenson, J. 2001 Teaching and Learning Online Pedagogies for New Technologies. London: Kogan Page.

Toffler, A. 1991 Future Shock. New York: Bantam Books.

Weller, M. J. 2002 'Pedagogies for online teaching', Delivering Learning on the Net, London: Kogan Page. 